\title{
Pituitary apoplexy induced by gonadotropin-releasing hormone agonist administration: a rare complication of prostate cancer treatment
}

\author{
Mariana Barbosa1, Sílvia Paredes', Maria João Machado², Rui Almeida2,3 and \\ Olinda Marques ${ }^{1,3}$
}

1Department of Endocrinology, 2Department of Neurosurgery, and 3Pituitary Consult, Hospital de Braga, Braga, Portugal
Correspondence should be addressed to M Barbosa

Email

marianamb013@gmail.com

\section{Summary}

Gonadotropin-releasing hormone (GnRH) agonists, currently used in the treatment of advanced prostate cancer, have been described as a rare cause of pituitary apoplexy, a potentially life-threatening clinical condition. We report the case of a 69-year-old man with a known pituitary macroadenoma who was diagnosed with prostate cancer and started treatment with $\mathrm{GnRH}$ agonist leuprorelin (other hormones were not tested before treatment). Few minutes after drug administration, the patient presented with acute-onset severe headache, followed by left eye ptosis, diplopia and vomiting. Pituitary MRI revealed tumor enlargement and T1-hyperintense signal, compatible with recent bleeding sellar content. Laboratory endocrine workup was significant for low total testosterone. The patient was managed conservatively with high-dose steroids, and symptoms significantly improved. This case describes a rare phenomenon, pituitary apoplexy induced by GnRH agonist. We review the literature regarding this condition: the pathophysiological mechanism involved is not clearly established and several hypotheses have been proposed. Although uncommon, healthcare professionals and patients should be aware of this complication and recognize the signs, preventing a delay in diagnosis and treatment.

\section{Learning points:}

- Pituitary apoplexy (PA) is a potentially life-threatening complication that can be caused by gonadotropin-releasing hormone agonist (GnRHa) administration for the treatment of advanced prostate cancer.

- This complication is rare but should be taken into account when using GnRHa, particularly in the setting of a known pre-existing pituitary adenoma.

- PA presents with classic clinical signs and symptoms that should be promptly recognized.

- Patients should be instructed to seek medical care if suspicious symptoms occur.

- Healthcare professionals should be aware of this complication, enabling its early recognition, adequate treatment and favorable outcome.

\section{Background}

Pituitary apoplexy (PA) is a potentially life-threatening clinical syndrome characterized by sudden onset of headache, vomiting, visual impairment and decreased consciousness, caused by bleeding and/or infarction of the pituitary gland, usually within a tumor (1). Androgen deprivation therapy, including gonadotropin-releasing hormone agonists (GnRHa), is administered as primary systemic therapy for regional or advanced prostate cancer 
and as neoadjuvant/concomitant/adjuvant therapy in combination with radiation in localized or locally advanced disease (2). GnRHa administration for prostate cancer has been reported to induce PA in patients with a concurrent pituitary adenoma, but there are only 21 cases described in the literature to date $(3,4,5,6,7,8,9,10)$. Although it is a rare complication, and since diagnosing PA requires high suspicion index, healthcare professionals should be aware of this association in order to enable an early recognition and adequate treatment.

\section{Case presentation}

A 69-year-old man with past medical history significant for diabetes, hypertension, dyslipidemia, Parkinson disease and cerebral falx meningioma had a pituitary macroadenoma $(11.5 \times 10.9 \times 9 \mathrm{~mm})$ incidentally detected in 2016 during workup for the meningioma Fig. 1. An endocrinology evaluation was requested but the patient failed to attend and was lost to follow-up. He was diagnosed with prostate cancer in 2017 and underwent retropubic prostatectomy; two years later there was evidence of histologic prostate tumor progression and he started on a GnRHa - a s.c. injection of leuprorelin $45 \mathrm{mg}$ every 6 months. A few minutes after the first injection, the patient presented with acute-onset severe persistent headache, followed by left eye ptosis 2 days later, diplopia and vomiting. He was observed by a neurosurgeon on the emergency department who confirmed left third cranial nerve palsy, with no other neurologic abnormalities. Remaining physical exam was unremarkable.

\section{Investigation}

Head CT with angiography showed pre-existing lesions: the tumor in the sellar region and the cerebral falx meningioma. Brain MRI was performed for further
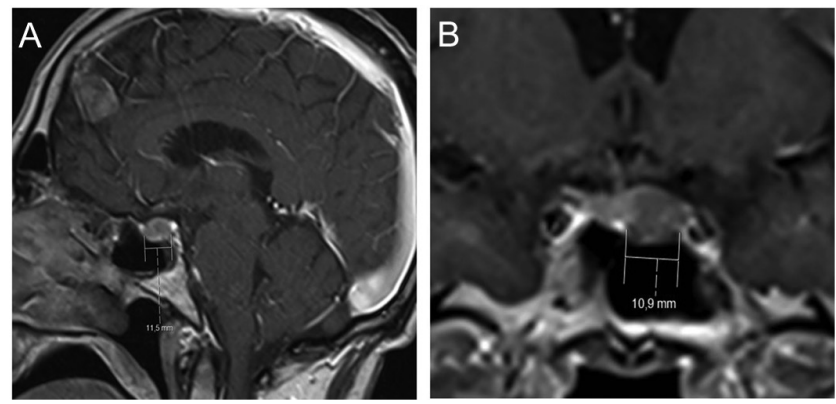

Figure 1

Gadolinium-enhanced T1-weighted pituitary MRI images with sagittal (A) and coronal (B) sections showing macroadenoma before apoplexy. clarification and revealed sellar tumor enlargement and a heterogeneous T1-hyperintense signal, compatible with recent bleeding sellar content, with extension to the left cavernous sinus (Knosp grade II) - Fig. 2. Laboratory workup was significant for total testosterone $72.1 \mathrm{ng} / \mathrm{dL}$ (86.5-788.2), with no other relevant abnormalities on pituitary cell lines or blood electrolytes as the sample was collected after steroid administration - Table 1.

\section{Treatment}

High-dose steroids - a $10 \mathrm{mg}$ dexamethasone i.v. bolus followed by $5 \mathrm{mg}$ of dexamethasone every $8 \mathrm{~h}$ - were started, with significant improvement of all clinical signs and symptoms, reason why the non-surgical approach was maintained. On discharge, the patient had complete resolution of the third nerve palsy, presenting with normal extraocular movements and no further headaches or vomiting. Dexamethasone was switched to methylprednisolone with tapering dose over 4 weeks and then replaced by hydrocortisone ( $15 \mathrm{mg} /$ day).

\section{Outcome and follow-up}

At two-month follow-up evaluation, the patient remained asymptomatic and biochemical workup revealed adrenocorticotrophic hormone $8.4 \mathrm{pg} / \mathrm{mL}(<46)$, cortisol $7.3 \mathrm{ug} / \mathrm{dL}$ (4.3-22.4) (sample collected $24 \mathrm{~h}$ after last hydrocortisone administration) and total testosterone 20 ng/dL (86.5-788.2), with no other biochemical remarks. He was maintained on hydrocortisone $15 \mathrm{mg} /$ day. A pituitary MRI was performed 4 months later that revealed tumor volume reduction, with T1-isointense signal, but heterogeneous features reflecting different stages of previous bleeding and reduced extension to the left
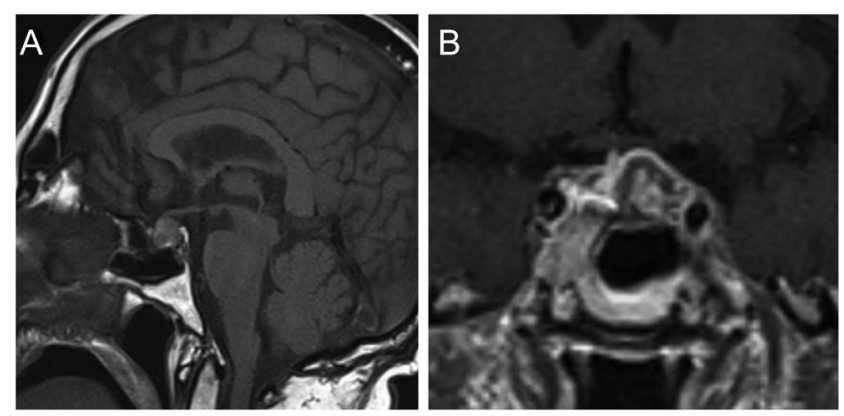

Figure 2

Non-contrast T1-weighted sagittal section (A) and gadolinium-enhanced T1-weighted coronal section (B) of pituitary MRI at presentation demonstrating sellar tumor enlargement and heterogeneous hyperintense signal compatible with pituitary apoplexy. 
Table 1 Laboratory workup at admission (after steroids administration)

\begin{tabular}{|c|c|c|}
\hline Laboratory test & Result & Reference range \\
\hline Cortisol, $\mu \mathrm{g} / \mathrm{dL}$ & 1.6 & $4.3-22.4$ \\
\hline ACTH, pg/mL & 10.8 & $<46$ \\
\hline $\mathrm{TSH}, \mu \mathrm{UI} / \mathrm{mL}$ & 0.3 & $0.4-3.7$ \\
\hline FT4, ng/dL & 0.9 & $0.8-1.5$ \\
\hline Prolactin, ng/mL & 0.5 & $2.1-17.7$ \\
\hline $\mathrm{GH}, \mathrm{ng} / \mathrm{mL}$ & 0.8 & $<3$ \\
\hline IGF-1, ng/mL & 147 & $37-219$ \\
\hline $\mathrm{FSH}, \mathrm{mUI} / \mathrm{mL}$ & 3.5 & \\
\hline $\mathrm{LH}, \mathrm{mUI} / \mathrm{mL}$ & 4.3 & \\
\hline $\mathrm{TT}, \mathrm{ng} / \mathrm{dL}$ & 72.1 & $86.5-788.2$ \\
\hline Sodium, mmol/L & 139 & $136-145$ \\
\hline Potassium, mmol/L & 3.8 & $3.5-5.1$ \\
\hline Creatinine, mg/dL & 0.9 & $0.7-1.2$ \\
\hline $\mathrm{CRP}, \mathrm{mg} / \mathrm{L}$ & 25 & $<3$ \\
\hline
\end{tabular}

ACTH, adrenocorticotropic hormone; CRP, C-reactive protein; FSH, follicle-stimulating hormone; FT4, free thyroxine; GH, growth hormone; IGF-1, insulin-like growth factor-1; LH, luteinizing hormone; TSH, thyroid-stimulating hormone; $\mathrm{TT}$, total testosterone.

cavernous sinus (Knosp grade I) - Fig. 3. Meanwhile, he was started on radiation therapy for prostate cancer.

\section{Discussion}

Prostate cancer is a prevalent disease, with an estimate of 174650 new cases in the United States to be diagnosed in 2019 , accounting for $20 \%$ of new cancer cases in men.

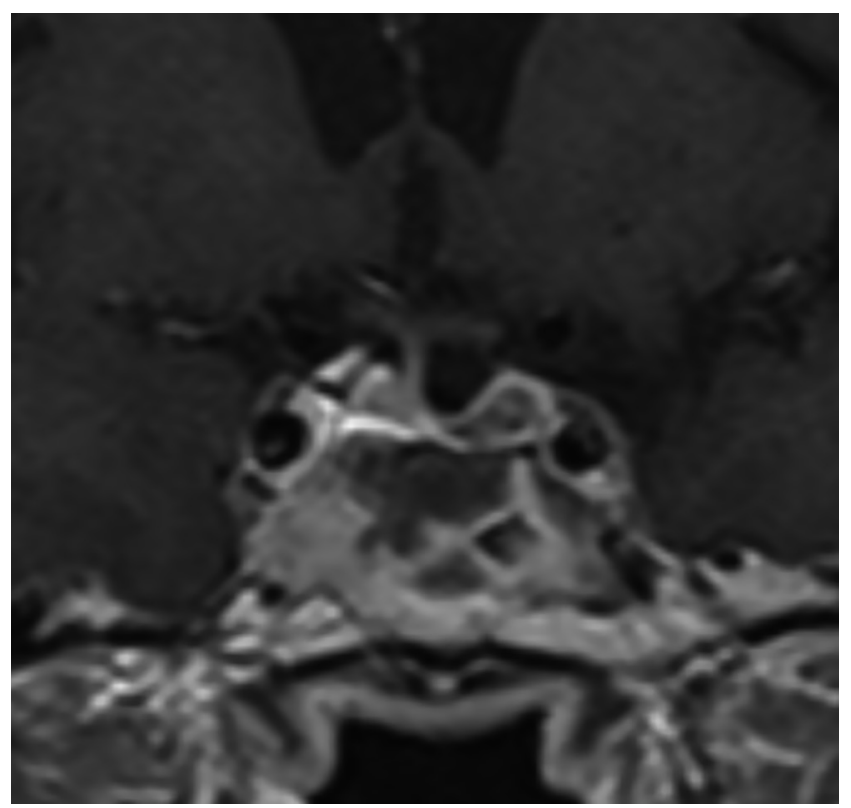

Figure 3

Gadolinium-enhanced T1-weighted coronal pituitary MRI image showing tumor volume reduction and isointense signal 4 months after apoplexy.
Hormonal therapy including GnRHa is an important modality of treatment in selected cases (2). Increasing use of GnRHa therapy has revealed a rare adverse drug reaction, the development of apoplexy in a pre-existing pituitary adenoma. We report a case of PA occurring minutes after the administration of leuprorelin in a patient with prostate cancer and a previously diagnosed pituitary macroadenoma.

The first case recording this condition was reported by Ando et al. in 1995 and since then 20 other cases have been published $(3,4,5,6,7,8,9,10)$ - Table 2 . Literature analysis of these reports revealed clinical features consistent with PA, highlighting pituitary MRI as the gold standard for diagnosis. Treatment decision on how to manage those patients - conservatively or with surgery - should be assessed by a multidisciplinary team (1). There are no randomized controlled trials and no evidence-based criteria to justify the clinical decision between a conservative approach and neurosurgical intervention. According to United Kingdom guidelines, patients with PA who are without any neuro-ophthalmic signs or mild and stable signs can be considered for conservative management with careful monitoring and frequent neurological assessments. On the other hand, patients with severely reduced visual acuity, severe and persistent or deteriorating visual field defects or deteriorating level of consciousness should be considered for surgical management (performed by an experienced pituitary surgeon and preferably within the first 7 days of symptoms onset). They emphasize that ocular paresis in the absence of visual field defects or reduced visual acuity is not in itself an indication for immediate surgery (resolution will typically occur within days or weeks) (1). Also, it is important to keep in mind that acute secondary adrenal insufficiency is seen in approximately two-thirds of patients with PA and is a major source of mortality. Therefore, initiating early glucocorticoid therapy is crucial in patients with PA and hemodynamic instability, altered consciousness level, reduced visual acuity, severe visual field defects or confirmed hypocortisolism. According to the literature, an i.v. bolus of hydrocortisone 100-200 mg is appropriate followed either by $2-4 \mathrm{mg} / \mathrm{h}$ continuous i.v. infusion or by 50-100 mg i.m. injection every $6 \mathrm{~h}$ (1). Dexamethasone is not favored as a glucocorticoid replacement option, although it may be used to reduce edema as part of nonsurgical strategy for PA treatment, as occurred in the case we report.

Review of the documented cases evidenced a mean age of 69.8 years (ranging from 60 to 85 years) at the event time. The majority of reported cases (11) occurred 
Table 2 Summary of reported cases of pituitary apoplexy induced by gonadotropin-releasing hormone agonists.

\begin{tabular}{|c|c|c|c|c|c|c|c|}
\hline Year & Reference & $\begin{array}{l}\text { Patient } \\
\text { age }\end{array}$ & $\begin{array}{l}\text { GnRH agonist, } \\
\text { dose }\end{array}$ & $\begin{array}{l}\text { Time of } \\
\text { onset }\end{array}$ & Symptoms/signs & $\begin{array}{l}\text { Pathological } \\
\text { findings }\end{array}$ & Treatment \\
\hline 1995 & (11) & 83 & $\begin{array}{l}\text { Goserelin, } \\
3.6 \mathrm{mg}\end{array}$ & 9 days & $\begin{array}{l}\text { Headache, nausea/vomiting, altered } \\
\text { mentation, diplopia, fever and } \\
\text { hyponatremia }\end{array}$ & - & Medical \\
\hline 1995 & $(12)$ & 78 & $\begin{array}{l}\text { Triptorelin, } \\
3.75 \mathrm{mg}\end{array}$ & $\begin{array}{l}\text { a few } \\
\text { min }\end{array}$ & $\begin{array}{l}\text { Headache, postural dizziness and left } \\
\text { partial ophthalmoplegia }\end{array}$ & - & Medical \\
\hline 1996 & (13) & 74 & $\begin{array}{l}\text { Leuprolide, } \\
7.5 \mathrm{mg}\end{array}$ & $15 \mathrm{~min}$ & $\begin{array}{l}\text { Headache, nausea/vomiting, left } \\
\text { ophthalmoplegia, altered mentation, } \\
\text { generalized weakness and visual } \\
\text { disturbances }\end{array}$ & $\begin{array}{r}\text { Stain } \mathrm{FSH}+ \\
\mathrm{LH}+, \mathrm{GH}+\end{array}$ & Surgical \\
\hline 1997 & (14) & 62 & $\begin{array}{l}\text { Leuprorelin, } \\
3.75 \mathrm{mg}\end{array}$ & 4 days & $\begin{array}{l}\text { Headache, left ophthalmoplegia and } \\
\text { papilledema }\end{array}$ & Stain FSH +, LH + & Surgical \\
\hline 2001 & (15) & 67 & $\begin{array}{l}\text { Goserelin, } \\
3.6 \mathrm{mg}\end{array}$ & $4 \mathrm{~h}$ & $\begin{array}{l}\text { Headache, nausea/vomiting, visual } \\
\text { disturbances, altered mentation and } \\
\text { hypertension }\end{array}$ & Stain $\mathrm{FSH}+, \mathrm{LH}+$ & Surgical \\
\hline 2002 & (4) & 74 & Leuprolide, - & - & Headache and nausea/vomiting & - & Medical \\
\hline 2003 & (16) & 69 & Leuprolide, - & $<4 \mathrm{~h}$ & $\begin{array}{l}\text { Headache, visual disturbances and } \\
\text { diabetes insipidus }\end{array}$ & Stain FSH + & Surgical \\
\hline 2006 & (17) & 68 & $\begin{array}{l}\text { Goserelin, } \\
3.6 \mathrm{mg}\end{array}$ & $4-6 \mathrm{~h}$ & $\begin{array}{l}\text { Headache, nausea/vomiting, altered } \\
\text { mentation, diplopia and right ptosis }\end{array}$ & - & Surgical \\
\hline 2006 & (18) & 61 & $\begin{array}{l}\text { Leuprolide, } \\
30 \mathrm{mg}\end{array}$ & $\begin{array}{l}\text { a few } \\
\text { hours }\end{array}$ & $\begin{array}{l}\text { Headache, nausea/vomiting, diplopia } \\
\text { and ophthalmoplegia }\end{array}$ & Stain FSH + & Surgical \\
\hline 2006 & (19) & 70 & $\begin{array}{l}\text { Leuprolide, } \\
11.25 \mathrm{mg}\end{array}$ & 10 days & $\begin{array}{l}\text { Visual disturbances, diplopia and } \\
\text { right ptosis }\end{array}$ & Stain FSH + & Surgical \\
\hline 2007 & (20) & 60 & $\begin{array}{l}\text { Leuprolide, } \\
22.5 \mathrm{mg}\end{array}$ & 4 hs & $\begin{array}{l}\text { Headache, nausea/vomiting, altered } \\
\text { mentation, visual disturbances, left } \\
\text { ophthalmoplegia and diplopia }\end{array}$ & Stain LH + & Surgical \\
\hline 2010 & (5) & 71 & Goserelin, - & 8 weeks & $\begin{array}{l}\text { Headache, nausea/vomiting and } \\
\text { visual disturbances }\end{array}$ & Stain FSH +, LH + & Surgical \\
\hline 2010 & (10) & 60 & Leuprolide, - & $\begin{array}{l}\text { a few } \\
\text { hours }\end{array}$ & $\begin{array}{l}\text { Headache, left ophthalmoplegia and } \\
\text { visual disturbances }\end{array}$ & Stain $\mathrm{LH}+$ & Surgical \\
\hline 2011 & (6) & 78 & $\begin{array}{l}\text { Goserelin, } \\
3.6 \mathrm{mg}\end{array}$ & 9 days & $\begin{array}{l}\text { Headache, left ophthalmoplegia and } \\
\text { visual disturbances }\end{array}$ & Stain FSH + & Surgical \\
\hline 2013 & (9) & 77 & $\begin{array}{l}\text { Leuprorelin, } \\
3.75 \mathrm{mg}\end{array}$ & $\begin{array}{l}\text { a few } \\
\text { hours }\end{array}$ & $\begin{array}{l}\text { Headache, nausea/vomiting and left } \\
\text { ophthalmoplegia }\end{array}$ & - & Surgical \\
\hline 2014 & (7) & 60 & Leuprolide, - & $\begin{array}{l}\text { a few } \\
\text { hours }\end{array}$ & $\begin{array}{l}\text { Headache, nausea/vomiting, diplopia } \\
\text { and left ptosis }\end{array}$ & Stain $\mathrm{LH}+, \mathrm{TSH}+$ & Surgical \\
\hline 2015 & (21). & 62 & $\begin{array}{l}\text { Leuprolide, } \\
11.25 \mathrm{mg}\end{array}$ & $10 \mathrm{~min}$ & $\begin{array}{l}\text { Headache, nausea/vomiting and right } \\
\text { ophthalmoplegia }\end{array}$ & Stain FSH +, LH + & Surgical \\
\hline 2015 & (8) & 77 & $\begin{array}{l}\text { Triptorelin, } \\
22.5 \mathrm{mg}\end{array}$ & $1 \mathrm{~h}$ & $\begin{array}{l}\text { Headache, nausea/vomiting, diplopia } \\
\text { and right ptosis }\end{array}$ & - & Surgical \\
\hline 2016 & $(22)$ & 67 & Triptorelin, - & 14 days & Headache and right ptosis & Stain $\mathrm{FSH}+, \mathrm{LH}+$ & Surgical \\
\hline 2016 & (23) & 63 & $\begin{array}{l}\text { Leuprolide, } \\
11.25 \mathrm{mg}\end{array}$ & 3 days & $\begin{array}{l}\text { Headache, visual disturbances and } \\
\text { altered mentation }\end{array}$ & - & Medical \\
\hline 2017 & (3) & 85 & $\begin{array}{l}\text { Leuprolide, } \\
45 \mathrm{mg}\end{array}$ & $4 \mathrm{~h}$ & Headache and nausea/vomiting & - & Medical \\
\hline
\end{tabular}

$\mathrm{FSH}$, follicle-stimulating hormone; GH, growth hormone; LH, luteinizing hormone; TSH, thyroid-stimulating hormone.

with leuprolide, whereas goserelin was implicated in five cases, triptorelin in three cases and leuprorelin in tw cases. The most variable parameter was time of symptom onset, occurring within minutes to several days after GnRHa administration. In 13 cases, symptoms developed within hours; the remaining patients presented clinical features 3 to 14 days after the injection, and in one case delayed PA was diagnosed 8 weeks after treatment. Headache was the predominant symptom, described in $95.2 \%$ of cases $(n=20)$, followed by nausea/vomiting in $61.9 \%(n=13)$, ophthalmoplegia and visual disturbances in $42.9 \%$ $(n=9)$, diplopia in $33.3 \%(n=7)$ and altered mentation status in $28.6 \%(n=6)$. Regarding treatment, surgical approach was conducted in $76.2 \%$ of cases $(n=16)$. As mentioned previously, while many patients with PA require surgical intervention, selected patients may be managed conservatively. In fact, our patient, despite the presence of a neuro-ophthalmic deficit, presented an 
excellent outcome with only medical treatment, possibly due to prompt evaluation and management. Histological findings with adenomatous tissue immunohistochemical staining were available in only 13 reports, all of them compatible with gonadotrophinomas (six positive for both luteinizing hormone (LH) and follicle-stimulating hormone (FSH), four positive for FSH and three positive for $\mathrm{LH})(3,4,5,6,7,8,9,10)$.

The exact pathophysiologic mechanism involved is this association is not clearly established. Multiple factors have been implicated in the increased risk of pituitary bleeding: larger size of the tumor, elevated intrasellar pressure and intrinsic vasculature abnormalities (9). Guerra et al. proposed a biphasic phenomenon, hypothesizing that PA induced by GnRHa can occur through an acute and a subacute phase (10). This concept of dual pathophysiology can reconcile the different features described in reported cases, especially concerning the timing of symptom onset. In cases where the condition occurred a few minutes or hours after drug administration (acute phase), a combination of cell degranulation/shrinking and metabolic hyperactivity in a poorly perfused adenomatous pituitary tissue (abnormal capillarity system) would explain the event. On the other hand, in the group of patients with a later start of symptoms (subacute phase), it was suggested that the stimulation of LH secretion leading to cell growth and protein synthesis could have an effect on tumor size and intrasellar pressure, promoting generalized ischemia and consequent bleeding $(8,10)$. Moreover, it has also been proposed that gonadotroph adenomas are the most common adenomas associated with the occurrence of PA. GnRHa binding to $\mathrm{GnRH}$ receptors on pituitary gonadotropin-secreting cells causes levels of LH and FSH to increase dramatically and this hormonal stimulation of gonadotrophs may be related to tumor growth, perpetuating tissue infarction (3). In fact, to our knowledge, only gonadotrophinomas were reported (both functioning and non-functioning (10)), despite co-staining for growth hormone (GH) in one case and thyroid-stimulating hormone (TSH) in another $(3,7)$.

Attending to the frequency of pituitary adenomas in the general population and the widespread use of GnRHa in prevalent diseases such as prostate cancer, along with the fact that pre-treatment pituitary hormone tests or imaging evaluation are probably not cost-effective, it is essential to draw attention to this possible complication $(7,8)$. In patients with a known pituitary adenoma, Babbo et al. recommended a thorough clinical evaluation and discussion by a multidisciplinary team including endocrinologists and neurosurgeons: in macroadenomas, surgical resection of the tumor prior to GnRHa therapy may be appropriate (given the higher likelihood of apoplexy in larger tumors), while in microadenomas, it may be suitable to cautiously proceed with GnRHa therapy (7). Nonetheless, regardless of the presence or absence of a known pituitary adenoma, both physicians who prescribe these drugs and patients should be informed and vigilant to the warning, clinical signs and act accordingly.

\section{Declaration of interest}

The authors declare that there is no conflict of interest that could be perceived as prejudicing the impartiality of the research reported.

\section{Funding}

This research did not receive any specific grant from any funding agency in the public, commercial or not-for-profit sector.

\section{Patient consent}

Written informed consent was obtained from the patient for publication of the submitted article and accompanying images.

\section{Author contribution statement}

All authors contributed to the case report and were included in the medical team that assisted the patient. Material preparation, data collection and literature review were performed by Mariana Barbosa. The first draft of the manuscript was written by Mariana Barbosa and all authors commented on previous versions, read and approved the revised and final manuscript.

\section{References}

1 Rajasekaran S, Vanderpump M, Baldeweg S, Drake W, Reddy N, Lanyon M, Markey A, Plant G, Powell M, Sinha S, et al. UK guidelines for the management of pituitary apoplexy. Clinical Endocrinology 201174 9-20. (https://doi.org/10.1111/j.13652265.2010.03913.x)

2 Mohler JL, Antonarakis ES, Armstrong AJ, D'Amico AV, Davis BJ, Dorff T, Eastham JA, Enke CA, Farrington TA, Higanoet CS, et al. Prostate cancer, version 2.2019, NCCN Clinical Practice Guidelines in oncology. Journal of the National Comprehensive Cancer Network 201917 479-505. (https://doi.org/10.6004/jnccn.2019.0023)

3 Tanios G, Mungo NA, Kapila A \& Bajaj K. Pituitary apoplexy: a rare complication of leuprolide therapy in prostate cancer treatment. BMJ Case Reports 2017. (https://doi.org/10.1136/bcr-2016-218514)

4 Spengos K, Pavlopoulos C \& Grivas A. Pituitary haemorrhage after leuprolide therapy for prostatic cancer, clinically imitating acute subarachnoidal haemorrhage. Cerebrovascular Diseases 200214272. (https://doi.org/10.1159/000065664)

5 Sinnadurai M, Cherukuri RK, Moses RG \& Nasser E. Delayed pituitary apoplexy in patient with advanced prostate cancer treated with gonadotrophin-releasing hormone agonists. Journal of Clinical Neuroscience 201017 1201-1203. (https://doi.org/10.1016/j. jocn.2010.01.012)

6 Ito Y. Unexpected enlargement of clinically silent pituitary gonadotroph adenoma induced by goserelin acetate given as 
treatment for prostate cancer. International Journal of Urology 201118 83-84. (https://doi.org/10.1111/j.1442-2042.2010.02676.x)

7 Babbo A, Kalapurakal GT, Liu B, Bajramovic S, Chandler JP, Garnett J $\&$ Kalapurakal JA. The presence of a pituitary tumor in patients with prostate cancer is not a contraindication for leuprolide therapy. International Urology and Nephrology 201446 1775-1778. (https://doi. org/10.1007/s11255-014-0708-z)

8 Guerrero-Pérez F, Marengo AP, Planas-Vilaseca A, Flores-Escobar V \& Villabona-Artero C. Pituitary apoplexy induced by triptorelin in patient with prostate cancer. Endocrinologia y Nutricion 201562 411-412. (https://doi.org/10.1016/j.endonu.2015.05.005)

9 Huang TY, Lin JP, Lieu AS, Chen YT, Chen HS, Jang MY, Shen JT, Wu WJ, Huang SP \& Juan YS. Pituitary apoplexy induced by gonadotropin-releasing hormone agonists for treating prostate cancer-report of first Asian case. World Journal of Surgical Oncology 201311 254. (https://doi.org/10.1186/1477-7819-11-254)

10 Guerra Y, Lacuesta E, Marquez F, Raksin PB, Utset M \& Fogelfeld L. Apoplexy in non functioning pituitary adenoma after one dose of leuprolide as treatment for prostate cancer. Pituitary 201013 54-59. (https://doi.org/10.1007/s11102-009-0202-2)

11 Ando S, Hoshino T \& Mihara S. Pituitary apoplexy after goserelin. Lancet 1995345 458. (https://doi.org/10.1016/s01406736(95)90443-3)

12 Chanson P \& Schaison G. Pituitary apoplexy caused by GnRHagonist treatment revealing gonadotroph adenoma. Journal of Clinical Endocrinology \& Metabolism 199580 2267-2278. (https://doi. org/10.1210/jcem.80.7.7608291)

13 Morsi A, Jamal S \& Silverberg JD. Pituitary apoplexy after leuprolide administration for carcinoma of the prostate. Clinical Endocrinology 199644 121-124. (https://doi.org/10.1046/j.13652265.1996.644465.x)

14 Reznik Y, Chapon F, Lahlou N, Deboucher N \& Mahoudeau J. Pituitary apoplexy of a gonadotroph adenoma following gonadotrophin releasing hormone agonist therapy for prostatic cancer. Journal of Endocrinological Investigation 199720 566-568. (https://doi.org/10.1007/BF03348020)
15 Eaton HJ, Phillips PJ, Hanieh A, Cooper J, Bolt J \& Torpy DJ. Rapid onset of pituitary apoplexy after goserelin implant for prostate cancer: need for heightened awareness. Internal Medicine Journal 2001 31 313-314. (https://doi.org/10.1046/j.1445-5994.2001.00065.x)

16 Hernandez Morin N, Huet D \& Hautecouverture M. Two cases of non-functional gonadotroph adenoma pituitary apoplexy following GnRH-agonist treatment revealing gonadotroph adenoma and pseudopituitary apoplexy after GnRH administration. Annals of Endocrinology 200364 227-231.

17 Błaut K, Wiśniewski P, Syrenicz A \& Sworczak K. Apoplexy of clinically silent pituitary adenoma during prostate Cancer treatment with LHRH analog. Neuro Endocrinology Letters 200627 569-572.

18 Davis A, Goel S, Picolos M, Wang M \& Lavis V. Pituitary apoplexy after leuprolide. Pituitary 20069 263-265. (https://doi.org/10.1007/ s11102-006-8616-6)

19 Massoud W, Paparel P, Lopez J-G, Perrin P, Daumont M \& Ruffion A. Discovery of a pituitary adenoma following treatment with a gonadotropin-releasing hormone agonist in a patient with prostate cancer. International Journal of Urology 200613 87-88. (https://doi. org/ 10.1111/j.1442-2042.2006.01237.x)

20 Hands KE, Alvarez A \& Bruder J M. Gonadotropin-releasing hormone agonist-induced pituitary apoplexy in treatment of prostate cancer: case report and review of literature. Endocrine Practice $2007 \mathbf{1 3}$ 642-646. (https://doi.org/ 10.4158/EP.13.6.642)

21 Sasagawa Y, Tachibana O, Nakagawa A, Koya D \& Iizuka H. Pituitary apoplexy following gonadotropin-releasing hormone agonist administration with gonadotropin-secreting pituitary adenoma. Journal of Clinical Neuroscience 201522 601-603 (https://doi. org/10.1016/j.jocn.2014.08.015)

22 Keane F, Egan A M, Navin P, Brett F \& Dennedy MC. Gonadotropinreleasing hormone agonist-induced pituitary apoplexy. Endocrinology, Diabetes \& Metabolism Case Reports 20162016160021 (https://doi. org/10.1530/EDM-16-0021)

23 Fabiano AJ \& George S. Pituitary apoplexy after Initial Leuprolide injection. World Neurosurgery 201695 616.e7-616.e9. (https://doi. org/10.1016/j.wneu.2016.08.091)

Received in final form 8 April 2020

Accepted 6 may 2020 